\title{
EFFECTS OF THE INDONESIAN NATIONAL REVOLUTION AND TRANSFER OF POWER ON THE SCIENTIFIC ESTABLISHMENT ${ }^{1}$
}

\author{
Adam Messer
}

Indonesian independence, and the subsequent transfer of sovereignty in 1949, changed the structure of scientific research organizations in that country. Prior to this date, vigorous research programs in many areas of pure and applied sciences were carried out under the auspices of Dutch-administered research institutes and universities. By precipitating an exodus of Dutch scientists, the transfer of power removed much of the intellectual capital from the Indonesian research effort.

To give some dimension to the direct effects of the transfer of sovereignty, this article provides an overview of research organizations and accomplishments prior to the Japanese occupation of Indonesia in 1942. Comparisons of directories of scientific research organizations and individuals, as well as close reading of scientific periodicals, provide an estimate of how independence transformed the research establishments. Interviews with Indonesian and Dutch scientists give an idea of how individual scientists perceived the transfer of power, and what the research environment was like at that time.

\section{Scientific Research in Indonesia before 1942}

The scale and accomplishments of the research establishments in Indonesia prior to the Japanese occupation are not well appreciated. The age of much of this work, and, curiously, the fundamental importance of many of the discoveries made during this era, are often forgotten.

The scientists working in this period were largely Dutch, complemented by researchers visiting from Europe and the United States. Virtually none of them were Indonesians. Writing in the scientific journal Nature, a senior Dutch science administrator reported that five native Indonesian scientists were active prior to 1939, at a time when probably 800-1,000

${ }^{1}$ I thank Prof. B. Anderson for his encouragement and guidance. Dr. A. Kostermans provided valuable information and insight. Suggestions made by Dr. D. Putman greatly improved the manuscript. 
Dutch investigators were working. ${ }^{2}$ Transplanted Dutch scientists made the discoveries chronicled below. ${ }^{3}$

Many advances in medicine and hygiene made by Dutch scientists in the East Indies transformed research in other parts of the world. The most notable of these discoveries, regarding vitamins, brought the Nobel prize to Dr. C. Eijkmann (1858-1930) in 1929. Eijkmann's experiments, carried out in military hospitals in Jakarta, established that soluble factors from rice husks protected against formation of beri-beri. This research established a paradigm for experimental approaches to nutritional sciences, and the leading medical research institute in Jakarta was named to honor Eijkmann. 4

Parasitic and vector-borne diseases took their toll on Dutch soldiers, colonists, and subjects. Through the efforts of physicians working at the Institute of Military Hygiene, as well as physicians serving in remoter areas, the etiology of diseases such as filariasis, leptospirosis, and mite fever was uncovered. ${ }^{5}$

Estate crops critical to the economic success of the Dutch presence in Indonesia generated research in tropical botany and agriculture. Implemented at various research stations throughout the Archipelago, as well as at the Experiment Station of the Central Association of Experiment Stations in Bogor, this agricultural research helped planters increase output, and at the same time added to the corpus of knowledge on Southeast Asian plants. ${ }^{6}$

In line with plantation agriculture was a fascination for tropical botany. Probably one of the most lasting, if not the most conspicuous, Dutch contribution prior to the Japanese occupation was the Botanical Garden at Bogor, and its associated institutes. The Herbarium dates to 1817 , when it was founded by C. G. G. Reinwardt. ${ }^{7}$ Because of its unique location in the center of one of the most botanically diverse regions on the earth, the Bogor garden was the preeminent institute of tropical botany, and gave the Dutch an advantage in Southeast Asian floristics which they have never lost. ${ }^{8}$

Zoological and phytochemical research was also conducted in conjunction with the Bogor gardens. Erected in 1888, the Laboratory for Chemical Investigation provided a locus for studies of plant chemicals of scientific and potential commercial importance. There was also some crossover between the phytochemists and medical and industrial researchers. Not surprisingly, tannins and quinine attracted much attention. ${ }^{9}$

\footnotetext{
2 P. Honig, Nature 151 (1943): 242-44.

3 The best source summary of scientific activities until the the Japanese occupation is: P. Honig and F. Verdoorn, eds., Science and Scientists in the Netherlands Indies (New York: Board for the Netherlands Indies, Surinam and Curacao, 1945).

4 W. F. Donath and A. G. van Veen, "A Short History of Beri-beri Investigations in the Netherlands Indies," in ibid., pp. 75-78; C. C. Gillespie, ed., Dictionary of Scientific Biography, 18 vols. (New York: Scribners, 1970-1990), vol. 4.

5 I. Snapper, "Medical Contributions from the Netherlands Indies," in Honig and Verdoorn, Science and Scientists, pp. 309-19.

6 F. A. F. C. Went, "A Short History of Botany in the Netherlands Indies," in ibid., pp. 390-403.

${ }^{7}$ Flora Malesiana, ser. I, vol. I, p. 429.

${ }^{8}$ C. J. Bernard, "Le jardin botanique de Buitenzorg et les institutions de botanique appliquée aux Indes Néerlandaises," in Honig and Verdoorn, Science and Scientists, pp. 10-15.

${ }^{9}$ C. Coster, "The Work of the West Java Research Institute in Buitenzorg," in ibid., pp. 55-58. D. R. Koolhaas, "Half a Century of Phytochemical Research," ibid.
} 
The development of many Dutch scientific disciplines was directly tied to the location of Indonesia in the Southern Hemisphere, as well as to a large number of the special features of the vast Archipelago. The enormous task of mapping the region, both for navigation and economic development, stimulated advances in hydrography and geology. In addition to charting seas, hydrographers published investigations of currents, salinity, temperature, and coral reef growth.

Geologists occupied themselves with exploration for minerals, metal ores, and fossil fuels. Indonesia offered seismologists and volcanologists important advantages-it straddles several tectonic plates so that there are frequent earthquakes and volcanic eruptions. ${ }^{10}$

The scientific paradise Indonesia provided for Dutch scientists is perhaps best illustrated by the story of Dr. F. A. Vening Meinesz (1887-1966). ${ }^{11}$ Vening Meinesz was a geodetic scientist by training, and his first job was determining local surface deviations in the Netherlands. These measurements of gravity were to correct the geographic positions of benchmarks used for triangulation surveys of Holland. One problem in the gravity survey was that the instrument used, which swung a single heavy pendulum and measured deviations from its expected arc, was very unstable on the frequently waterlogged ground. Vening Meinesz invented an instrument that compensated for this kind of instability by using two pendulums. He immediately realized the importance of his gravity measuring device; it could be used at sea.

The significance of this discovery has to be set in the context of geophysical science in the 1910s and 1920s. According to the isostatic theory current at the time, big blocks of the earth's crust "floated" on a viscous medium. Continents could be thought of as relatively light blocks; thus they floated higher than the denser crustal blocks containing oceans. British teams had determined that the Himalayas were relatively mass deficient, and there were some indications that the rock layers underlying the oceans were relatively dense. Determining the nature of the suboceanic crust became critical for testing the validity of the isostatic theory. A survey of the oceans was needed to determine if the entire underlying mass was as dense as theory predicted.

For such a survey of the Indonesian ocean basins, Vening Meinesz enlisted the cooperation of the Dutch Navy. His instruments were installed in submarines. Gravity surveys of the East Indies were conducted between 1923 and 1927, and Vening Meinesz discovered several strips of negative anomalies in which the oceanic crust was lighter than predicted. This result stood in direct contradiction to the isostatic theory. The naturally occurring geological diversity of the Indonesian ocean basins provided numerous examples of these negative anomalies, and Vening Meinesz's research led to revisions in the isostatic theory. The Dutch Navy benefited from the valuable hydrographic information produced by the collaboration, especially after the invention of remote bottom sounders (sonar).

Astronomers profited from the Southern Hemisphere location of the Bosscha observatory, placed just outside Bandung. They compiled a long series of observations on double stars and parallaxes. These observations, in which the position of stars is determined relative to a common point of reference such as a constellation, allow astronomers to estimate

\footnotetext{
${ }^{10}$ A. L. ter Braake, "Volcanology in the Netherlands Indies," in ibid., pp. 22-35; C. P. Brest van Kempen, "Earthquakes in the Netherlands Indies," ibid.

11 R. M. Field, "Felix Alexander Vening Meinesz, Exponent of International Cooperation through Geoscience," in ibid., pp. 99-104; Gillespie, Dictionary of Scientific Biography, vol. 11.
} 
stellar distances. European astronomers gravitated to the Bosscha observatory, and other parts of the Archipelago, to observe periodic solar eclipses. ${ }^{12}$

Founded by a tea planter, the Bosscha observatory was unique because it was the only privately funded institute of basic research in the Indies. Other privately administered institutes, such as the Central Rubber Research Institute, and the Research Institute of the Sumatra Planters' Association, conducted applied research on economically important plant products.

The Bosscha observatory, because it was an individually funded organization, provides an exception to the first of three general factors which seem responsible for the vigor of the research effort in colonial Indonesia prior to World War II. The first factor was institutional support. Funding and facilities for research, whether provided by the government or private consortia, established a base of operations from which serious research could be conducted. On a symbolic level, this institutional support suggests that research priorities were understood by administrators, and taken seriously.

Scientists were the second factor. The Netherlands East Indies received an energetic, well-trained corps of researchers. Economic conditions prevailing in the Netherlands undoubtedly motivated many Dutch scientists to move to Indonesia. Dr. A. Kostermans related that, in 1936, twelve of his classmates from Utrecht moved to Indonesia because they were not able to find suitable jobs in their fields in the Netherlands. ${ }^{13}$ The general impression is that researchers migrated because they wanted to work within their profession, and not simply take whatever job turned up at home.

The third factor undoubtedly had to do with the special nature of Indonesia itself. The country had the kind of novelty and diversity which inspires exciting research.

World War II provided some evidence for the health and independence of the scientific establishment in Indonesia. There was no contact between scientists in Indonesia and the Netherlands. ${ }^{14}$ But scientific journals produced in Indonesia continued to publish research results as late as March 1942, almost two years after German troops occupied the Netherlands. ${ }^{15}$

\section{Scientific Research after the Japanese Occupation}

The Japanese occupation devastated scientific research in Indonesia, although a few papers were published by the Japanese on medicinal plants. ${ }^{16}$ Most of the Dutch scientists were interned, and the small number who were able to remain in their positions faced severe restrictions of material and supplies. The few Indonesian scientists and medical workers toiled on in the interim, improvising substitutes for critical research supplies. A

12 G. P. Kuiper, "Astronomy in the Netherlands Indies," in Honig and Verdoorn, Science and Scientists, pp. 22126.

13 Several interviews and conversations with Dr. Kostermans were held in $1987-89$, when we were both affiliated with BIOTROP, the Southeast Asian Regional Center for Tropical Biology, in Bogor.

14 This is according to Kostermans, who remained in Indonesia until the Japanese occupation and his subsequent imprisonment and transport to Thailand.

15 While many journals bear publication dates of 1942, the specific example is De Bergcultures. Source: World List of Scientific Periodicals (Washington: Butterworths, 1963-65).

${ }^{16}$ Kostermans has copies of these in his data bank of economically useful plants of Southeast Asia, at the Bogor Herbarium. 
report in the Indonesian Medical Journal of the time details the method by which the agar growth medium from used petri plates can be recovered and reused.17

After the Japanese surrender, Dutch scientists returned to Indonesia, undoubtedly with the expectation that the prewar status quo would be resurrected. Many scientists, after being reunited with their families, opted to return to the Indies to take up their previous jobs, or to complete earlier research work. In their introductions to monographic articles, authors frequently state that their researches were interrupted by the Japanese occupation, or that they had plenty of time to think about their research while "down in the coal mines."18

Another indication of the Dutch expectation that they would rapidly reconstruct the scientific base of the Indies came from the activities of expatriate Dutch in the United States. ${ }^{19}$ Under the auspices of the Board for the Netherlands Indies, Surinam, and Curacao, the Central Depository Library for the Netherlands Indies was established in New York City in 1943. The goal of the Depository Library was to maintain subscriptions to scientific periodicals held in Indonesia, and purchase new books in line with specialities of each particular library. The plan was an enlightened one aimed at preventing gaps in journal coverage by any of the major research libraries. Similar activities, carried out by the Netherlands Government Commission for Scientific Documentation in London, suggested that colonial administrators keenly appreciated the need to maintain some sort of scientific continuity in the East Indies.

If the pace at which a bureaucracy was created to activate scientific research is any indication, there was a major effort on the part of the Dutch colonialists to preserve the momentum and maintain scientific continuity. Authorized by an act of Lieutenant GovernorGeneral van Mook in May 1948, the Organisatie voor Natuurwetenschappelijk Onderzoek (Organization for Scientific Research, abbreviated herein as the OSR) became the umbrella organization coordinating research in all branches of the natural sciences in Indonesia. ${ }^{20}$ Table 1 lists the research institutes placed under OSR control. The OSR published a newsletter under various English and Dutch titles (Table 2), which documents the last few years of the Dutch scientific establishment in Indonesia.

\section{Sequelae to the Transfer of Sovereignty}

The transfer of sovereignty from Dutch to Indonesian governments took place on December 27, 1949. The OSR was not immediately affected, although its journal printed those government decrees which might have some impact on science in the country.

Perhaps the first of these was a "nationalization" decree. ${ }^{21}$ Empowering the minister of culture, education, and instruction to do whatever he thought necessary to make the University of Indonesia satisfy the "national tendencies of the Republic of the United States of Indonesia," this regulation was directed at bringing domestic talent into the University of

\footnotetext{
17 Sardjito, Madjalah Dokter Indonesia 2 (1949): 279.

18 A. C. V. van Bemmel, Treubia 19 (1950): 323.

19 J. F. Engers, "The Board for the Netherlands Indies, Surinam and Curacao," in Honig and Verdoorn, Science and Scientists, pp. 461-62; P. Honig and F. Verdoorn, "The Central Depository Library for the Netherlands Indies in New York City," in ibid., pp. 462-65.

${ }^{20}$ The full text of the ordinance is given in Dutch, Indonesian and English in: Organization for Scientific Research Bulletin No. 1 (1948), 27 pp.

${ }^{21}$ The decree is printed in O.S.R. News 2 (February 1950): 18-19. Editorial comment appears on the first page of the same journal number.
} 
Table 1. Institutes under the Organization for Scientific Research

\begin{tabular}{|c|c|c|}
\hline & Name & Location \\
\hline $\begin{array}{l}1 . \\
2 . \\
3 . \\
4 . \\
5 . \\
6 . \\
7 . \\
8 . \\
9 . \\
10 . \\
11 . \\
12 . \\
13 . \\
14 . \\
15 . \\
16 . \\
17 . \\
18 . \\
19 . \\
20 . \\
21 . \\
22 . \\
23 . \\
24 . \\
25 . \\
26 .\end{array}$ & $\begin{array}{l}\text { Botanic Gardens and affiliates } \\
\text { General Agricultural Expt. Station } \\
\text { Forest Research Institute } \\
\text { Veterinary Institute } \\
\text { Institute for Sea Fishery } \\
\text { Central Bureau for Technical Research } \\
\text { Laboratory for Testing Materials } \\
\text { Ceramic Institute } \\
\text { Textile Institute } \\
\text { Division of Seafisheries } \\
\text { Central Bureau for Industrial Research } \\
\text { Central Fibre Institute } \\
\text { Laboratory for Chemical Research } \\
\text { Batik Experiment Station } \\
\text { Commercial Museum } \\
\text { Leather Experiment Station } \\
\text { Gutta Percha Laboratory } \\
\text { Laboratory for Soil Mechanics and Road Technique } \\
\text { Hydraulic Laboratory } \\
\text { Royal Magnetic and Meterological Observatory } \\
\text { Pasteur Institute } \\
\text { Eykmann Institute } \\
\text { Laboratory for Technical Hygiene } \\
\text { Military Hygenic Institute } \\
\text { Geographical Institute } \\
\text { Geodetical Institute }\end{array}$ & $\begin{array}{l}\text { Bogor } \\
\text { Bogor } \\
\text { Bogor } \\
\text { Bogor } \\
\text { Jakarta } \\
\text { Jakarta } \\
\text { Bandung } \\
\text { Bandung } \\
\text { Bandung } \\
\text { Jakarta } \\
\text { Jakarta } \\
\text { Bandung } \\
\text { Bogor } \\
\text { Bandung } \\
\text { Jakarta } \\
\text { Jogjakarta } \\
\text { Cipetir } \\
\text { Bandung } \\
\text { Bandung } \\
\text { Jakarta } \\
\text { Bandung } \\
\text { Jakarta } \\
\text { Bandung } \\
\text { Jakarta } \\
\text { Jakarta } \\
\text { Jakarta }\end{array}$ \\
\hline
\end{tabular}

Source: Organization for Scientific Research, Bulletin No. 1, October 1948.

Table 2. Title and Language Information for Natural Science Newsletters

\begin{tabular}{cclc}
\hline \hline Year & \multicolumn{1}{c}{ Organization Name } & \multicolumn{1}{c}{ Journal Title } & Language \\
\hline 1949 & $\begin{array}{l}\text { Organisatie voor } \\
\text { Natuurwetenschappelijk }\end{array}$ & $\begin{array}{l}\text { Bulletin Organisatie voor } \\
\text { Natuurwetenschappelijk Onderzoek }\end{array}$ & Dutch \\
1950 & $\begin{array}{l}\text { Organization for Scientific } \\
\text { Research in Indonesia }\end{array}$ & O.S.R. News & English \\
1951 & $"$ & & $"$ \\
1952 & $"$ & Journal for Scientific Research & " \\
1953 & " & & $"$ \\
1954 & " & & $"$ \\
\hline
\end{tabular}

As given on the masthead of the first number of the newsletter for each year. 
Indonesia. While Dutch professors descried the possibility that this legislation would cause the standards of the universities to sink, and that the emphasis on national problems would remove the Indonesian universities from the international community of scholars, practical effects on research itself were equivocal. A professor of physics, and director of the Physics Department at the Technical Institute at Bandung, Dr. S. Broersma, recalled that the nationalization decree had virtually no impact on scientific research in his department. ${ }^{22}$ Rather, he recollected, the effect of the decree was to shift Indonesian administrators into positions formerly held by Dutch citizens. Dr. A. Kostermans, a professor in Bandung, remembered that while the new administrators were eager to maintain the previous educational standards, they did not appreciate what this might entail in the early 1950s. Kostermans said that he was "invited to leave" his teaching post after half of his students received failing marks. ${ }^{23}$

From the Indonesian perspective the Nationalization Decree, and the Higher Education Decree (1946) mandating that lectures be delivered in Indonesian, probably represented a reaction to the overwhelming Dutch presence in the universities. ${ }^{24}$ For example, the Technical Faculty in Bandung listed twenty professors, all Dutch, and four deputy professors, only two of whom were Indonesians. Similar situations prevailed in the Faculty of Mathematics and Natural Sciences (nine Dutch professors) and the Agricultural Faculty (eleven "foreign" professors; one Indonesian deputy professor). The Medical Faculty in Jakarta contributed one of the few exceptions to this trend-in early 1952, twelve of thirteen professorships were held by Indonesians.

The trend toward increasing Indonesian participation in medicine was reflected in medical organizations. For perspective, it is worth noting that the Public Health Service employed 633 physicians in 1941, with 850 additional medicos otherwise engaged in private practice. In 1954, 783 physicians and dentists were on the rolls of the Public Health Service; information on private physicians is not recorded in the census of that year. Averaged across the Archipelago, then, there was on the order of one physician per 50,000 inhabitants. ${ }^{25}$

The relations between established Dutch medical organizations and a newly created society of Indonesian doctors seem to have been strained. After the founding of the Ikatan Dokter Indonesia (IDI) in 1950, the 99-year-old Society for the Furthering of Medical Sciences in Indonesia decided to cease its activities. In terminating the society, Dr. R. Gispen stated that the intent of this action was to "remove any hindrance which might interfere with an independent scientific development in Indonesia." 26 Gispen hoped that eliminating the Society for the Furthering of Medical Sciences in Indonesia would generate close cooperation among Indonesian scientists. The events motivating the decision to close down the society were not discussed.

22 Telephone interview conducted May 5, 1986 with Dr. S. Broersma.

${ }^{23}$ Kostermans, interviews in Bogor, 1987.

24 "Extracts from a Speech of the President of the University of Indonesia Delivered on the 2nd February at Bandung," Journal for Scientific Research 1 (1952): 75-78.

25 Statistics extracted from Central Kantoor voor de Statistik, Statistical Pocketbook of Indonesia 1941; Biro Pusat Statistik Djakarta, Statistik 1956.

${ }^{26}$ Events surrounding creation of the Ikatan Dokter Indonesia are described in the November 1950 issue of O.S.R. News. The quotation is from: R. Gispen, "Termination of the Activities of the Society for the Furthering of Medical Sciences in Indonesia," O.S.R. News 2 (1950): 142-43. 
While the membership policies of the Society for the Furthering of Medical Sciences are not known, the creation of the IDI, and the wording of its charter, suggest that the Dutch medical establishment may have excluded many Indonesian doctors from its ranks. Elements of Indonesian nationalism can be detected in the membership policies of the IDI. Writing in the OSR newsletter, Dr. Sarwono Prawirohardjo explained that "[p]reviously several groups of physicians had their own societies which operated independently of one another. This situation can no longer be maintained." The provisional constitution of the IDI specified that foreign physicians could be admitted only as nonvoting associate members of the society, so that the IDI would remain exclusively under the management of Indonesian citizens. ${ }^{27}$

That Indonesian doctors moved quickly to found their own medical society, and constituted the majority of the medical faculty, may reflect the relatively advanced training of these professionals. Many of these doctors would have been academic equals to their Dutch counterparts. Graduates of STOVIA, the medical school founded by the Dutch in Indonesia at the turn of the century, received a degree which entitled them to practice medicine in the Netherlands. ${ }^{28}$ Kostermans, who knew many of the medical graduates and whose brother was on the staff of the Eijkmann Institute, recalled that most of the STOVIA graduates were Chinese Indonesians. ${ }^{29}$

The diminished Dutch involvement in Indonesian medical societies was reflected in the major medical research institutes in Jakarta. Comparisons of directories of scientific research published in November 1949 and January 1952 (Table 3), indicate major changes in the stated purpose of the institutes, replacement of Dutch staff by Indonesians, and gutting of the institutes' libraries. The library of the Eijkmann Institute shrank by a factor of 12 , to 15,000 volumes from 175,000 volumes, a modest wound compared to the 60 -fold loss suffered by the library of the Institute for Military Hygiene. ${ }^{30}$

The loss of library resources registers as a distinct contrast to the fastidious efforts made during World War II to maintain overseas subscriptions to journals received by the medical institutes. A catalog issued by the Central Depository Library enumerates all volumes received from overseas sources after the war, and lists the libraries in Indonesia to which these books were sent. ${ }^{31}$ Although exactly what happened to the library collections is uncertain, this loss reduced the access of Indonesian medical scientists to the technical literature. There are indications that many books disappeared with the departing Dutch. $32 \mathrm{~A}$ remark

27 S. Prawirohardjo, in ibid., p. 142.

28 Snapper, "Medical Contributions," pp. 309-19.

${ }^{29}$ Telephone interview with A. Kostermans, December 1989.

${ }^{30}$ Library statistics and other information compiled from comparisons of Organization for Scientific Research Bulletin No. 3 (1949) and No. 11 (1952).

${ }^{31} \mathrm{~W}$. van der Brugghen, Centrale Catalogus van de Centrale Natuurwetenschappelijke Bibliotheek, Organization for Scientific Research Bulletin No. 2 (1948).

32 Dr. A. Kostermans, who was on the faculty of the Technical University in Bandung, said that there was a scheme to dissolve the library of the Royal Physical Society in Jakarta, and sell the building. After the books were rebound in Bogor, they were installed in a building in Bandung purchased with the proceeds of the sale of the library building in Jakarta. Some books were stolen by Dutch persons who were forced to leave Indonesia in the late 1950s; most of the rest of the collection was neglected and is now useless because the remaining books have been damaged by humidity and insects. 
Table 3. Transformation of Jakarta Medical Research Institutions

\begin{tabular}{|c|c|c|}
\hline & November 1949 & January 1952 \\
\hline Name: & Eijkmann Instituut & Eykmann Institute \\
\hline Purpose: & $\begin{array}{l}\text { Scientific investigations concerning } \\
\text { public health problems. }\end{array}$ & $\begin{array}{l}\text { Scientific and practical investigation of } \\
\text { control of contagious and endemic } \\
\text { diseases, for improvement of public } \\
\text { health in Indonesia; furthermore clini- } \\
\text { cal chemical and diagnostic investiga- } \\
\text { tions; education center for secondary } \\
\text { and lower grade personnel. }\end{array}$ \\
\hline Director: & Dr. R. Gispen & Dr. R. Abdoelrachman \\
\hline Staff: & $\begin{array}{l}\text { Miss Dr. J. C. Lanzing, } \\
\text { Dr. D. G. E. R. Kostermans } \\
\text { Dr. C. D. Westermann }\end{array}$ & $\begin{array}{l}\text { Miss Dr. J. C. Lanzing } \\
\text { Dr. M. Erber }\end{array}$ \\
\hline Library: & 175,000 volumes & 15,000 volumes \\
\hline \multirow{4}{*}{$\begin{array}{l}\text { Name: } \\
\text { Purpose: }\end{array}$} & Militair Hygiënsich Instituut & Institute of Military Hygiene \\
\hline & $\begin{array}{l}\text { 1. Study of military-hygenic problems. } \\
\text { 2. Postgraduate tropical course for } \\
\text { military surgeons }\end{array}$ & Unchanged \\
\hline & 3. Education of technical assistants & \\
\hline & 4. Army-hospital laboratory-research & \\
\hline Director: & Dr. G. F. Kotter & Dr. R. Moh. Azil Widjajakusumah \\
\hline Sub-Director: & Dr. R. Harnopidjati & no category \\
\hline Staff: & $\begin{array}{l}\text { Dr. W. de Graaf } \\
\text { Drs. H. A. Bakker } \\
\text { Th. H. Cowan } \\
\text { Miss Drs. E. J. Rijkebusch }\end{array}$ & $\begin{array}{l}\text { Dr. W. de Graaf } \\
\text { Dr. Pudriasi Harnopidjati } \\
\text { M. Mowoka } \\
\text { Mohd. Izak } \\
\text { Kustijo } \\
\text { R.P. Sukmadjidjaja }\end{array}$ \\
\hline Library: & 6,000 volumes & about 100 volumes \\
\hline Name: & Instituut voor Volksvoeding & Nutrition Institute \\
\hline Purpose: & $\begin{array}{l}\text { Scientific investigations concerning } \\
\text { nutrition }\end{array}$ & Improvement of the diet of the people \\
\hline Director: & M. K. Velds & Dr. Poorwo Soedarmo \\
\hline Staff: & $\begin{array}{l}\text { Dr. R. Luyken } \\
\text { Dr. J. V. Klerks } \\
\text { E. Samuels-Brusse }\end{array}$ & \\
\hline Library: & None listed & None listed \\
\hline
\end{tabular}


attached to the description of the Central Military Library reports that " 40 to 50 thousand volumes were missing after the transfer from the K.N.I.L." 33

Changes in the statements of purpose of the two civilian medical research institutes suggest that under the direction of Indonesian physicians, priorities shifted from basic medical research to applied problems and training. The Eijkmann Institute stated that it was involved in "practical investigations," as well as education of health technicians. Under a new Indonesian director, the Institute of Nutrition Research devoted itself to "improvement of the diet of the people," a theme later stressed by President Soekarno. ${ }^{34}$

\section{Personnel Changes after the Transfer of Power}

Two factors rapidly brought Indonesians into control of the research institutes and the OSR. First, an exodus of Dutch scientists in the early 1950 s created many vacancies in administrative and research positions. Second, under a policy of nationalization, there was also pressure to replace the heads of the institutes with Indonesians.

Disturbed by the possible departure of many staff scientists, the Executive Board of the OSR polled the institutes to determine how serious the problem might become. ${ }^{35}$ The results of this survey, shown in Table 4, indicate that about half of the staff scientists in the OSR institutes in 1950 had decided to leave by 1952. Since already in 1950 there was a shortage of scientific staff in the institutes, the Executive Board calculated that at best they would be left with only one-third of the required staff. Writing to the High Commissioner in July 1950, the board noted that this shortage would hinder development and economic reconstruction, and make it increasingly difficult for new scientists to establish themselves in the country, because there would be no "old-timers" around to show them the ropes.

Table 4. Scientific Personnel in OSR Institutes

\begin{tabular}{lccc}
\hline \hline & January 1950 & January 1952 & Desired \\
\hline Academic Trained & 143 & 58 & 226 \\
\% of January 1950 & 100 & 41 & \\
College Trained & 60 & 33 & 100 \\
\% of January 1950 & 100 & 55 & \\
\hline
\end{tabular}

Census of scientific personnel in Institutes under the control of the Organization for Scientific Research. Figures for January 1950 are actual counts; figures for 1952 were compiled from a survey of OSR scientists. Source: Journal for Scientific Research 3 (1951): 95.

Reports published by some of the OSR research institutes in mid-1951 indicate that the staff shortage had become severe enough to interfere with research and surveying tasks. ${ }^{36}$ Difficulties in transportation, and lack of books and research equipment, made it hard to

33 Organization for Scientific Research Bulletin No. 11 (1952).

34 Speech delivered to the First National Science Congress, Malang, August 1958. Printed in Laporan Kongres Ilmu Pengetahuan Nasional I, pp 7-23.

35 This section of the annual report is summarized in: O.S.R. News 3 (1951): 87.

36 A. W. J. H. Hoitink, "The Institute of Physiology at Bogor (Indonesia)," ibid., pp. 192-95; J. P. J. de Groot, "Hydrographical Service for Indonesia," ibid., p. 189. 
carry out entomological research. ${ }^{37}$ The private Research Institute for Estate Crops reported that most of its expatriate staff left between 1956 and 1958. ${ }^{38}$

Migration statistics for Indonesia suggest that the scientific personnel might not have been different from the majority of Dutch. Figure 1 shows that in 1940 more than twice as many Dutch entered Indonesia as left it. By 1950, however, departing the country became five times more popular than staying. From 1950 to 1955, there was a net outflow of Dutch, in contrast to the situation before 1940. Thus, the movement of Dutch scientists out of the country was not some extraordinary side-effect of the transfer of sovereignty, but was part of the mass movement of Dutch citizens from Indonesia.

The factors driving this massive emigration are beyond the scope of this paper, but the biographical and professional background presented below on scientists may provide a basis for understanding the motivation of researchers to stay or leave.

One of the immediate effects of Dutch emigration was to create vacancies on the boards and oversight committees of the OSR. Tables 5-7, comparing the composition of the Governing Board, the Executive Board, and the Secretariat, indicate that two major types of changes took place in the governance and administration of the OSR. First the size of these bodies decreased, apparently due to the departure of Dutch scientists. Second, by 1951, Indonesians held the majority of posts on the Governing and Executive Boards, and an Indonesian became head of the Secretariat.

This transformation of the OSR bureaucracy was reflected in the research institutes under its domain. Following a policy of putting the research institutes under the control of Indonesians, the OSR in 1950 turned the leadership of thirteen of the thirty-six institutes over to Indonesians. Eighteen institutes remained under Dutch heads, and five were closed. ${ }^{39}$ Tables 5-7 show the pattern of the Indonesians' assumption of control of the OSR, and the institutes under its jurisdiction, resulting from implementation of the Indonesianization policy and the filling of new vacancies.

Determining how independence and the transfer of power changed life for Dutch scientists might indicate why so many of them left Indonesia, and why at the same time many others came there from Holland. The following section explores the rationale behind the decisions of Dutch scientists to stay on in or come to Indonesia after the transfer of sovereignty, and also examines the motivation of those who left. This discussion is based largely on interviews with Dr. S. Broersma, an emeritus professor of physics at the University of Oklahoma; Dr. W. Meijer, professor of botany at the University of Kentucky in Lexington; Dr. A. Kostermans, a scientist at the Herbarium Bogorense; Dr. Ir. Roosseno Soerjohadikoesoemo, formerly a faculty member at the Bandung Technical Institute but now with his own engineering firm in Jakarta; and correspondence with the now deceased Dr. M. A. Lieftinck, who had been associated with the Zoological Laboratory in Bogor, and later the Rijksmuseum in Leiden.

Dr. Kostermans' recollections were especially valuable to this study, and justify a brief biographical note. Born in 1906 in Purworedjo, he received his primary education in Yogyakarta, and all but the last year of his secondary education in Bandung. Following a final year of secondary education in Maastricht, he enrolled in the University of Utrecht, and went on

\footnotetext{
${ }^{37}$ Idea 8 (1950): $1-3$.

38 "General Information of the Research Institute for Estate Crops," February 20, 1969 (stenciled pamphlet, Balai Penelitian Perkebunan Bogor, 10 pp.).

${ }^{39}$ O.S.R. News 3 (1951): 87.
} 


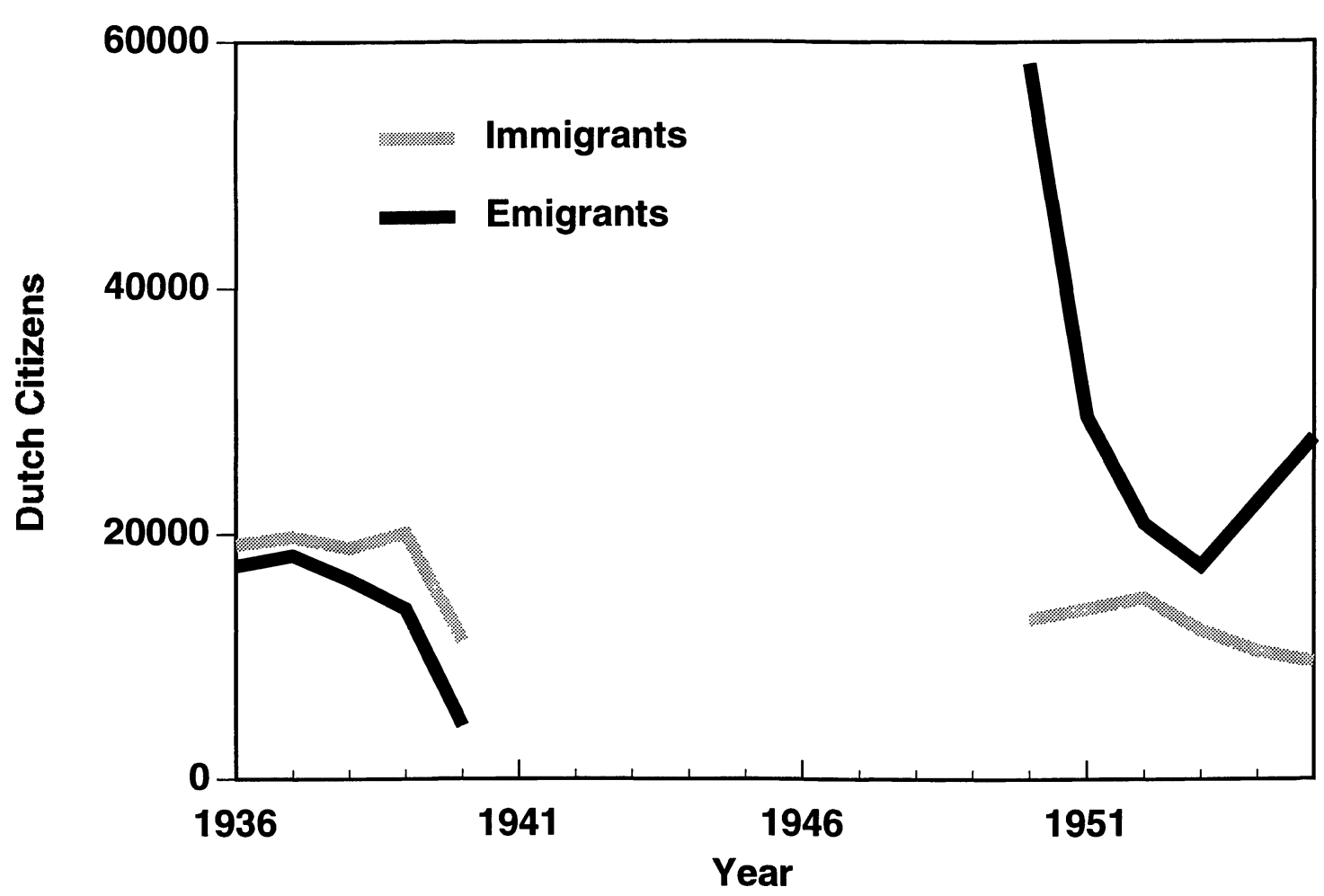

Figure 1. Migration patterns of Dutch citizens entering and leaving Indonesia. There is a net emigration after 1950. Data not available for 1941-1949. Sources: Central Kantoor voor de Statistik, Statistical Pocketbook of Indonesia 1941; Biro Pusat Statistik Djakarta, Statistik 1956. 
Table 5. Members of OSR Governing Boards,1949-1953

\begin{tabular}{lll}
\hline \hline 1949 & 1950 & 1951 \\
\hline S. Eman & S. Eman & Ir. Tan Tak Bheng \\
D. Bennick & D. Bennick & Ir. J. A. Nijholt \\
Drs. P. Braber & (departed) & Prof. Ir. R. Kusnoto \\
Dr. Ir. J. C. Defize & Dr. Ir. J. C.Defize & Mr. R. M. Harsojo \\
Dr. G. W. Fris & Dr. G. W. Fris & (departed?) \\
Mr. M. v. L.-Biemond & Mr. M. v. L.-Biemond & Mr. M. v. L.-Biemond \\
Dr. R. Sukanto & Dr. R. Sukanto & Dr. R. Sukanto \\
Ir. J. Bellingwort & (departed) & Dr. J. P. J. de Groot \\
Dr. J. K. Baars & $?$ & Dr. Ir. van der Bie \\
Prof. F. A. van Baron & $?$ & Dr. W. J. van Essen \\
Prof. Ir. v. d. Heuvel & Prof. Ir. v. d. Heuvel & Prof. Ir. v. d.Heuvel \\
Prof. Dr. A. Grevenstuk & Prof. Dr. A. Grevenstuk & ? \\
Ir. J. van der Ploeg & $?$ & \\
Dr. F. K. Wawo Roentoe & Dr.F. K. Wawo Roentoe & Dr. F. K. Wawo Roentoe \\
\hline 12 Dutch, 2 Indonesian & 7 Dutch, 2 Indonesian & 6 Dutch, 5 Indonesian \\
\hline
\end{tabular}

1953 (September)

Dr. F. K. Wawo Roentoe

Prof. Ir. R. Kusnoto

Ir. Tan Tak Bheng

Ir. J. A. Nijholt

Dr. Poorwo Soedarmo

Dr. R. Soekanto

Dr. J. P. J. de Groot

A. Aldjufri

2 Dutch, 6 Indonesian

Membership of OSR Governing Boards, with estimated composition by citizenship. Names have been arranged to provide continuity across columns wherever possible; this arrangement does not represent the hierarchy within the OSR Governing Board. When available, the fate of a missing member has been given in parentheses. Source: 1949-1951-Annual Reports of the Organization for Scientific Research in the OSR News (2 [1950]: 51; 3 [1951]: 82) and the Journal for Scientific Research (1 [1952]: supplement). Board members for 1953 determined from the second cover of the Journal for Scientific Research issued in September 1953. 
Table 6. Members of OSR Executive Boards, 1949-1953

\begin{tabular}{lll}
\hline 1949 & 1950 & 1951 \\
\hline Dr. Ir. P. Honig & $?$ & Dr. F.K. Wawo Roentoe \\
Dr. Ir. C. v.d. Giessen & (departed) & Dr. J. Schweitzer \\
Dr. H. Hardon & Dr. Hardon (left Oct '50) & Dr. Ir. Roosseno \\
Ir. G. J. Wally & Ir. G. J. Wally & \\
Prof. Dr. Berlage & Prof. Dr. Berlage (left Sept '50) & \\
Prof. R. Gispen & (departed) & Prof. Dr. Abdoelrachman \\
Prof. Dr. Baas-Becking & (?departed) & Dr. Poorwo Soedarmo \\
Col. N. Gerharz & (departed) & R. Djaenoedin \\
Dr. Ir. v. Blommenstein & (did not return after leave) & Ir. G. Broersma \\
\hline 9 Dutch & 3 Dutch & 2 Dutch, 5 Indonesian \\
\hline
\end{tabular}

1953

Dr. F. K. Wawo Roentoe

Prof. Dr. R. Abdoelrachman

Dr. Ir. Roosseno

Dr. J. Schweitzer

R. Djaenoedin

1 Dutch, 4 Indonesian

Composition of Executive Boards of the OSR 1949-1953, with estimated composition by citizenship. Names have been arranged to provide continuity across columns wherever possible; this arrangement does not represent the hierarchy within the OSR Executive Board. When available, the fate of a missing member has been given in parentheses. Source: 1949-1951-Annual Reports of the Organization for Scientific Research in the OSR News (2 [1950]: 51-52; 3 [1951]: 83) and the Journal for Scientific Research (1 [1952]: supplement). Board members for 1953 determined from the second cover of the Journal for Scientific Research issued in September 1953. 
Table 7. Members of OSR Secretariat, 1949-1953

\begin{tabular}{|c|c|c|c|}
\hline Position & 1949 & 1950 & 1951 \\
\hline $\begin{array}{l}\text { 1. Chairman } \\
\text { Acting Chairman } \\
\text { Vice-Chairman }\end{array}$ & $\begin{array}{l}\text { Ir. G. J. Wally } \\
\text { Dr. H. P. Berlage }\end{array}$ & $\ldots \ldots .$. & Dr. F. K. Wawo Roentoe \\
\hline 2. General Secretary & Ir. G. Broersma & Ir. G. Broersma & Ir. G. Broersma \\
\hline $\begin{array}{l}\text { 3. Scientific Secretaries } \\
\text { i. } \\
\text { ii. } \\
\text { iii. } \\
\text { iv. }\end{array}$ & $\begin{array}{l}\text { Dr. A. C. d. L.-Sloep } \\
\text { Ir. C. J. Mol } \\
\text { Chr. N. J. van Beveren } \\
\text { vacant }\end{array}$ & …... & $\begin{array}{ll}\cdots \cdots \cdots . \\
\cdots \cdots \cdots . . \\
\cdots \cdots \cdots . .\end{array}$ \\
\hline 4. In charge of Documents & Miss C. M. Schaap & Miss C. M. Schaap & Miss C. M. Schaap \\
\hline 5. General Affairs & Mrs. L. B.-Graafland & Mrs. M. Megens & H. D. Tjoa \\
\hline 6. Archivist & Mrs. M. Megens & Mrs. M. Megens & Raden Moh. Joesof \\
\hline 7. Secretary & Miss L. Janse & Mrs. I. Broersma & Mrs. I. Broersma \\
\hline
\end{tabular}

Composition of Secretariat of the OSR 1949-1951, as listed in Annual Reports. A complete list of the Secretariat was not issued in 1953; however Mrs. M. L. Waworoentoe is listed as fulfilling the functions of Secretary and Scientific Organizer. Source: 1949-1951-Annual Reports of the Organization for Scientific Research in the OSR News (2 [1950]: 51-52; 3 [1951]: 83) and the Journal for Scientific Research (1 [1952]: supplement). Members for 1953 determined from the second cover of the Journal for Scientific Research issued in September 1953. 
to complete a Ph.D. in Botany in 1936. He received a Treub Fellowship to go to Indonesia in 1936 for two years. Unable to find a position in the Netherlands, Kostermans stayed in Indonesia and taught organic chemistry beginning in 1938. He was imprisoned by the Japanese, and sent to Thailand to labor on the Quemoy railroad from 1942 to 1945 . After his release, he remained for two years in Thailand, collecting plants for Dr. E. Merrill, of the Harvard University Herbaria. Kostermans returned to Java in 1947, and joined the Forestry Research Institute in Bogor, and beginning in 1949 he also held a faculty appointment at the technical university in Bandung. He became an Indonesian citizen in 1957. One of the most prolific describers of plant species, he retired from the Forestry Research Institute and his faculty position in 1969. During his 80th year, Kostermans and the author took a rough field trip to Pamungpeuk, Kecamatan Garut, to collect flowers of the only remaining individual of an undescribed tree species.

Of the major factors motivating Dutch scientists to leave Indonesia, the financial situation was one of the most important. An example of this was Professor Broersma, director of the Physics Department at the Technical Institute in Bandung from 1949-1951, who left to accept a position at Northwestern University. The factors motivating his departure had nothing to do with any philosophical disagreement over independence. Rather, practical considerations accelerated his decision. After independence, his salary was paid partly in Indonesian rupiah, and partly in Dutch guilders. Inflation was so severe, that salaries were not very attractive.

Corroboration of the importance of the salary issue comes in a speech delivered by Dr. L. A. van der Woerd at the inauguration of the Faculty of Medicine in Surabaya in 1951. Read in the presence of the minister of education, instruction, and culture, Dr. Bahder Djohan, van der Woerd's speech raised this issue:

Formerly this country was a favorable exception [to the rule that scientific workers were underpaid], now the living costs are 20 times as high as 10-12 years ago, and conditions are just as bad, probably even worse than in the rest of the world. 40

Better living and working conditions might compensate for the reduced salaries, but in their absence van der Woerde guaranteed that research workers would move away. The article introducing the speech noted that the number of foreign physicians was steadily diminishing. This situation continued as inflation worsened. An analysis of Indonesian economic conditions shows that between 1953 and 1955, prices of fifteen imported goods nearly doubled, while local food prices rose by only 38 percent. ${ }^{41}$ The increased price of foreign goods would have been felt keenly by expatriate workers.

The financial stringency, however, did not force all Dutch scientists to leave. Dr. Kostermans, for example, said that the inflation was very bad and cut his salary in half; but to bring in extra money during these years, he accepted invitations to teach as a visiting professor at universities in Denmark, the Netherlands, and the United States.

Salary issues were also not the most important thing to Dr. Meijer. ${ }^{42}$ After an inspirational speech given at his university in the Netherlands by the most illustrious Dutch botanist in Indonesia, Dr. C. J. J. van Steenis, Meijer inquired about going to Bogor. It

\footnotetext{
${ }^{40}$ L. A. van der Woerd, "Some Questions Which Arise to the Pharmacologist in Indonesia," O.S.R. News 3 (1951): 54-55.

41 J. A. C. Mackie, The Indonesian Economy 1950-1963 (Frankfurt: A. Metzner Verlag, 1964). Inflation is discussed on p. 147.

42 Telephone interview with Dr. W. Meijer, May 21, 1986.
} 
seemed like a place where an idealistic young biologist could find work, undertake some fascinating research, and participate in the development of Indonesia. So Dr. Meijer arrived in Bogor in 1951.

He was paid 900 rupiah a month, which translated into about $\$ 100$ US at the time. Initially Meijer was paid in rupiah in Indonesia; three years later he was able to arrange for some of his salary to be deposited in guilder accounts in the Netherlands. Compared to other foreign researchers, Dutch scientists seemed the most poorly paid; Dr. Meijer remarked that Swedish scientists working in Indonesia earned 2000 rupiah per month. Meijer maintained that his salary was adequate, though perhaps he became worse off later on as inflation grew. As an indication of this, he said that tempe was a staple because meat was too expensive to eat more than once a week.

Among Dutch scientists, Meijer said, there were two types: those who favored Indonesian independence and those who did not. This division roughly corresponded to those who had been in Indonesia before the war, and those who came afterwards.

Other factors made the lives of Dutch scientists difficult. Professor Broersma described the scene in Bandung as one of chaos. There seemed to be a general lack of municipal organization, which made the city an unpleasant place to live. Dr. Kostermans said that it was not easy to buy food, because many vendors did not want to sell to Dutch residents, and he often had to send his adopted Indonesian children to shop for him. A major asymmetry of wealth was apparent between the university departments and the people outside the gates. Fully equipped research labs, filled with newly imported European instrumentation, contrasted with an Indonesian population clothed in rags. The gradient of wealth, Professor Broersma said, was extreme. Thefts of laboratory equipment-instruments such as voltmeters, ammeters, and batteries-possibly useful in radio repair, became a big problem.

With about four years to go on his posting in Indonesia, Professor Broersma decided to leave. Applying for and receiving Indonesian citizenship would have been necessary if he had desired to stay on in the country and continue teaching, but the salary issue was his major consideration. To emphasize that point, he pointed out that a number of top-flight Indonesian researchers and engineers, notably his friend Dr. Ir. Roosseno, preferred to remain in the private sector because they could not adjust their standard of living downward to match prevailing salaries at academic institutions. Listed as a "Private Engineer, specializing in concrete and steel structures" in a Curriculum Vitae published in 1951, Roosseno was attached to the Bandung branch of the University of Indonesia as a Professor extraordinarus. 43

Professor Broersma's descriptions of the general outlook that had existed among the scientific community in early 1949 are especially interesting. Virtually everyone had agreed that the transfer of sovereignty would take place, perhaps in five years, perhaps longer. It was the rapidity of the change that startled the Dutch community, because there was some sense that too few Indonesians had been sufficiently trained to maintain a stable infrastructure.

Finally, Dr. Broersma said that the biggest loss Indonesia sustained after independence was not wealth, but brains. Dr. Roosseno concurred with this assessment, noting that there were many technical difficulties after the Dutch began to leave. ${ }^{44}$ The intellectual capital of

\footnotetext{
43 O.S.R. News 3 (1951): 166-67.

44 Interview with Dr. Ir. Roosseno in Jakarta, April 16, 1989. Roosseno, incidentally, had been Soekarno's employer before the latter became heavily involved in political activity. Chosen by the Japanese to become a
} 
the country, represented by a generation of Dutch scientists with research experience in Indonesia, was lost.

After English or Indonesian were mandated as replacements for Dutch as languages of instruction, several further problems developed. Dr. Roosseno said that while in theory the change was a good idea, there were a number of practical problems. There was no technical literature available in Indonesian, so that lecture notes had to take the place of books. Dr. Meijer recalled that some of the Dutch professors could not speak Indonesian and few of the students understood English. There was virtually no botanical literature available in Indonesian. Dr. Meijer felt that the nationalism evident in the shift away from Dutch was misplaced. The result was that a massive scientific literature suddenly became unavailable, and that Indonesia was largely cut off from current scientific developments because of a language barrier. Other newly independent states, Meijer explained, notably India and Malaysia, maintained their colonial language in the universities, and have developed excellent domestic scientific establishments.

Asked to comment on the exodus of Dutch scientists from the country after independence, Meijer said that one factor might have been that many of the scientists, particularly those who had come to Indonesia before World War II, were reaching retirement age in the early 1950s.

Dr. Meijer left Bogor in 1954, and accepted a university position in West Sumatra. Assigned to the Ministry of Education, Culture, and Instruction, he implemented agricultural education programs.

So in spite of the salary and organizational hardships, some Dutch scientists elected to remain in the newly independent country. Primarily involved in the systematics and biology of plants and animals, these scientists probably had several incentives to stay on. Unlike physicists and chemists, their expertise could not be readily transferred. Because the organisms they specialized on usually did not range beyond Southeast Asia, they would have had little opportunity to utilize their scientific knowledge in a different biogeographic realm. Although there are many biological similarities between Indonesia, Malaysia, and the Philippines, the latter two countries were already the turf of, respectively, British and American scientists. In the absence of any acceptable opportunities in Asia or the Netherlands, these natural history researchers saw remaining in Indonesia as the best alternative.

Dr. M. A. Lieftinck's research activities may illustrate why Dutch naturalists did not leave. ${ }^{45}$ Chief of the Zoological Museum of the Bogor Botanical Gardens, Lieftinck concentrated on aquatic insects and bees. Long field trips to many parts of the Archipelago were required for this work, which involved observing insects and collecting them for systematic studies in the museum. Patterns of diversity discussed in Lieftinck's publications represent more than a list of insect species new to science. Based on studies of unique geographic realms, these publications sketch how biogeography and evolution work on island archipelagos. Despite the shortages and internal difficulties present in Indonesia in the early 1950s, Lieftinck and his co-workers were able to get to some of the remoter parts of the country. An expedition to the Moluccas is recorded in 1953.

member of the citizens' committee set up to aid preparations for independence, Roosseno was minister of public works under Soekarno, from 1953 to 1955.

45 Notes on Lieftinck prepared from his papers published in Treubia, as well as correspondence, in particular a letter to me of February 1, 1984. 
Lieftinck retired to the Netherlands in 1961, and continued to work on collections transferred to the Rijksmuseum in Leiden. He also ceded direct editorial responsibility for the zoological journal Treubia in that year.

The preceding section has discussed personnel changes that took place after the transfer of power, but this information does not reveal much about how these factors transformed the research establishment in Indonesia.

\section{Indonesian Scientific Journals after the Transfer of Power}

Further insight into the effects of the transfer of power on the Indonesian scientific establishment can be gained through an analysis of technical publications edited in Indonesia. The idea is not to evaluate the research, but rather to see who the authors were and where they came from. One hypothesis is that increased Indonesian participation in the research effort should have translated into more Indonesian authors of journal articles.

Journals result from a process of editing and production which demands tight coordination between authors, editors, and printers. Simple analysis of journal statistics might provide a diagnosis of the health of the infrastructure responsible for issuing the publications. Title changes of journals might also reflect transformations in the government or society of the time, or prevailing fashions.

This treatment of journals will first consider name changes and publication histories of several publications in different research fields. More detailed analysis of authorship patterns and page counts will consider mainly the leading journals reporting basic research in zoology (Treubia) and botany (Reinwardtia).

The results of a survey of some journals edited in Indonesia around 1950 are compiled in Table 8. ${ }^{46}$ The table presents name changes and publication dates when they could be obtained. At least two journals, Tectona, a journal of forestry, and Landbouw, an agricultural journal, ceased publication in the early or mid-1950s without undergoing any name changes. Several other journals which did show a name change also ceased publication about this time. Thus a change of name did not necessarily ensure the vitality of a journal.

Name changes took several forms. In the simplest case, a journal title simply dropped the descriptor "Nederlandsch-Indië," as in the case of the journals devoted to rubber and tea cultivation. Or, in addition to dropping the descriptor, a wholly new title was created, usually through translation of the earlier title and the addition of the word "Indonesia."

Some new titles leave no evidence of any national affiliations. The journal of the Royal Physical Society in Jakarta bore the name Chronica Naturae between 1947 and 1950. The notes of the Netherlands Indies veterinary service became Hemera Zoa, which glosses as "Domesticated Animals." A complex series of title changes ultimately left the title Reinwardtia on the major scientific organ of the Bogor Botanical Garden. Reinwardtia and Treubia were named after an eminent botanist, and zoologist, respectively.

The society or organization publishing a journal also left a mark on the journal title. With the departure of the Society for the Furthering of Medical Science in the East Indies, its journal Medisch Maanblad evolved into Madjalah Kedokteran Indonesia, the official monthly of the Ikatan Dokter Indonesia. Reemerging after World War II, the journal of the Entomological

\footnotetext{
46 This table was prepared from bibliographies presented in van der Brugghen, "Centrale Catalogus," and a list in Honig and Verdoorn, "Central Depository Library," p. 464. Title information and publication dates were extracted from the World List of Scientific Periodicals and the National Union Catalog.
} 
60 Adam Messer

Table 8. Transformation of Selected Journals

Type of Change

Extinction

Title Changes

a) Loss of Dutch Identity

b) Change in publishing organization

c) Straightforward

d) Complex

New Journals

\section{Example and date}

Tectona: boschbouwkundig tijdschrift, 1908-1955

Landbouw, 1925-1953

Archief voor de rubbercultuur in Nederlandsch-Indië 1917-1941

Archief voor de rubbercultuur 1948-1953

Archief voor de theecultuur in Nederlandsch-Indie 1927-1941

Archief voor de theecultuur 1948-1955

Medisch Maanblad 1946-1950

Madjalah Kedokteran Indonesia 1950-

De Bergcultures 1926-1957

Menara Perkebunan 1958-

Nederlandsch-Indische bladen voor diergeneeskunde 1918-1948

Hemera Zoa 1949-

Tijdschrift voor Indische Taal-, Land-en Volkenkunde 1852-1948

Madjalah untuk ilmu bahasa, ilmu bumi, dan kebudajaan Indonesia 1948

De Tropische Natuur: orgaan van de Nederlandsch-Indische Natuur-

Historische Vereeniging 1912-1953

Penggemar alam 1954-1957

Wetenschappelijke mededeelingen van de Dienst van de mijnbouw in Nederlandsch-Oost-Indië. Publikasi keilmuan. Djawatan geologi, Republik Indonesia 1955-1957

Natuurkunding tijdschrift voor Nederlandsch-Indië (Jakarta) 1850-1940. Natuurwetenschappelijk tijdschrift voor Nederlandsch-Indië (Weltevreden) 1941-1946.

Chronica Naturae (Jakarta) 1947-1950

Indonesian Journal for Natural Science 1951-

Madjalah Ilmu Alam Untuk Indonesia 1951-

Verhandelingen der K. magentisch en meteorologisch Observatorium te Batavia 1911-1941

Verhandelingen Lembaga Meteorologi dan Geofisik 1947-1961

Bulletin de l'Institut botanique de Buitenzorg 1898-1905

Bulletin du Département de l'agriculture aux Indes-néerlandaises 1906-1911

Bulletin du Jardin botanique de Buitenzorg 1911-1940

Bulletin of the Botanic Gardens, Buitenzorg 1941-1950

Reinwardtia 1950-

Madjalah kesehatan angkatan perang 1951-1959

Madjalah kesehatan mulut dan gigi 1953-

Madjalah persatuan dokter gigi Indonesia 1950-

Madjalah pertanian 1953

List from W. van der Brugghen, Centrale Catalogus van de Centrale Natuurwetenschappelijke Bibliotheek, OSR Bulletin No. 2 (October 1948). Further information and title information from: Peter Brown and George Stratton eds., World List of Scientific Periodicals, 4th ed. (London: Butterworth, 1963). 
Society of Indonesia changed to Idea from Entomologische mededeelingen van NederlandschIndie. The new journal title is an acronym based on the Latin ita disciplinam entomologicam agimus. Idea is also the genus of Idea hypermnestra, a tropical forest butterfly the behavior of which the Entomological Society took as a metaphor for its role. The butterfly is bright and conspicuous in otherwise dark tropical forests; this was supposed to symbolize the emergence of the Entomological Society and its journal from the war years. Not surprisingly, the first editor of the newly reincarnated journal was a lepidopterist. ${ }^{47}$

The transformation of the title of the journal reporting results of the magnetic and meteorological services is somewhat enigmatic. An approximate Indonesian language equivalent was substituted for the Dutch name of the magnetic and meteorological observatory publishing this journal, but the first word in the title remained "Verhandelingen," or "Proceedings."

After independence, then, the general rule is that journal titles changed to reflect the new status of Indonesia. Removing the Dutch names for the country Indonesia (i.e. Nederlandsch-Indië), substituting translations into Indonesian of Dutch titles, or eliminating any apparent national affiliation in a new title appear to have been some of the methods by which titles were brought into harmony with independence.

This process was hastened, however, by a decree issued on December 1, 1957. An emergency cabinet meeting was held on that Sunday morning to consider the assassination attempt on President Soekarno the previous night, and the continuing Dutch occupation of West Irian (now Irian Jaya). As a response to the Dutch occupation, the government banned all publications and films in Dutch. 48

The ramifications of this decree were especially great for those journals which had not already begun to publish anything in English or Indonesian. A preface to the newly renamed Menara Perkebunan, the journal of plantations research formerly known as De Bergcultures, stated that it should not surprise readers that the conflict in Irian had affected all corners of life. Thus, commensurate with the circulation of the first English and Indonesian number of the journal, Dutch persons were struck from the editorial board. Only after receiving special permission from the Information Ministry was the journal allowed to publish at all, and this was with a reduced frequency due to personnel shortages. ${ }^{49}$

If journal titles reflected a new Indonesian enthusiasm for, and participation in, scientific research, then it can be argued that this enthusiasm should have led to an increase in the number of research reports published by Indonesians in domestically edited journals. To test this hypothesis, the two leading Indonesian journals reporting basic research results in botany and zoology, Reinwardtia and Treubia, were analyzed. ${ }^{50}$

These journals were chosen because i) they were basic science journals with a long publication history before and after the transfer of sovereignty, ii) they treat Indonesian natural

\footnotetext{
47 Idea 8 (1950): 1-3. The editor of the revitalized Idea was Dr. A. Diakonoff.

48 Harian Penerangan, December 2, 1957, p. 1; Times of Indonesia, December 2, 1957, p. 1. The decree also prohibited sending news out of the country about the Irian conflict or the assassination attempt. News of these events was to come only from official or military sources, through a censor.

49 Des Bergcultures, December 16, 1957; Menara Perkebunan, January 1, 1958.

${ }^{50}$ Counts were made of the number of authors listed on each contents page. Each author was counted only once, regardless of how many papers he or she published. The criterion for foreign authorship was a correspondence address outside Indonesia. Determination of Indonesian authors was made on the basis of a subjective evaluation of last names, based on criteria which are easy to apply and understand, but difficult to explain.
} 


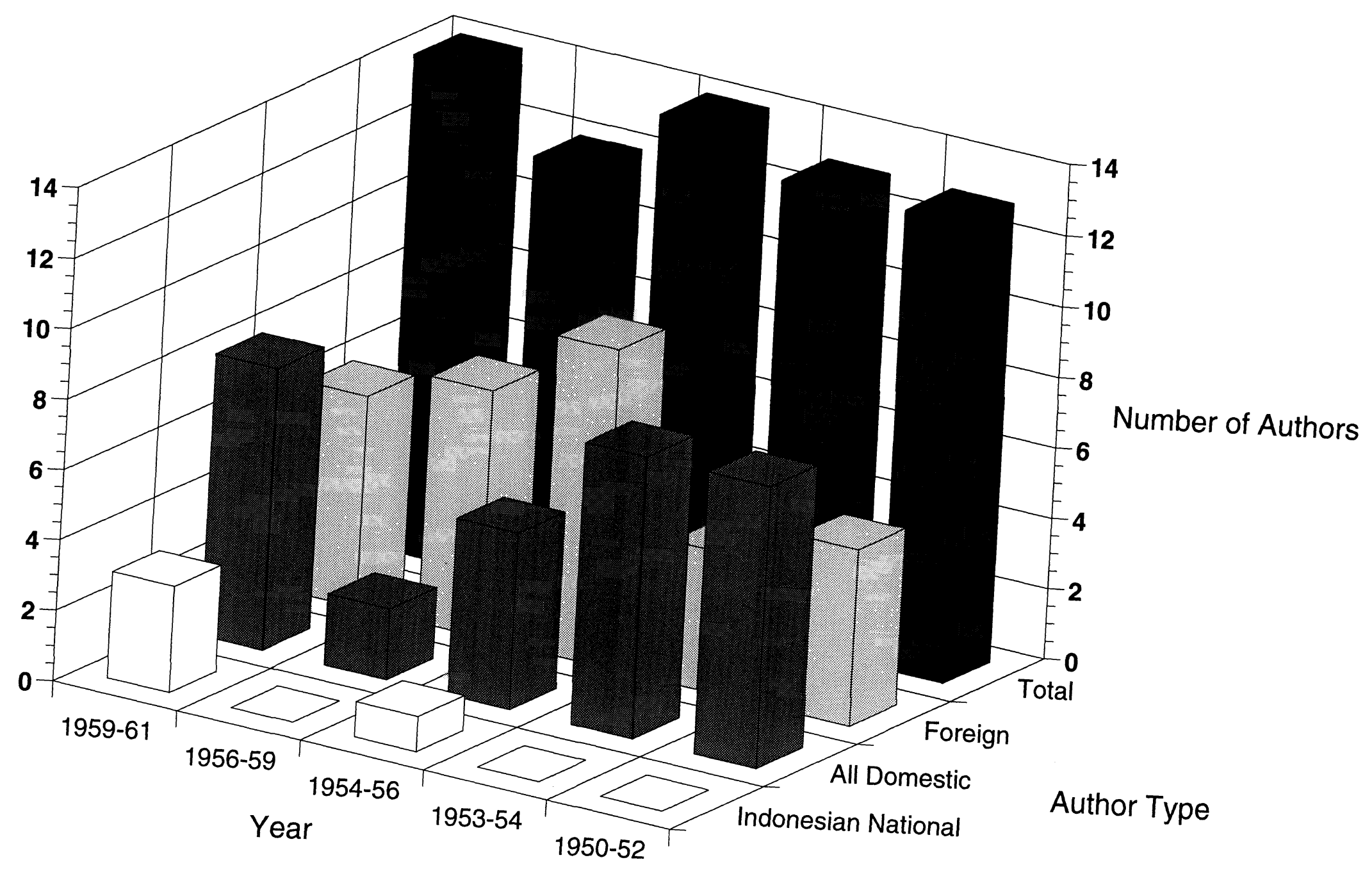

A. Reinwardtia authorship patterns, 1950-1961 


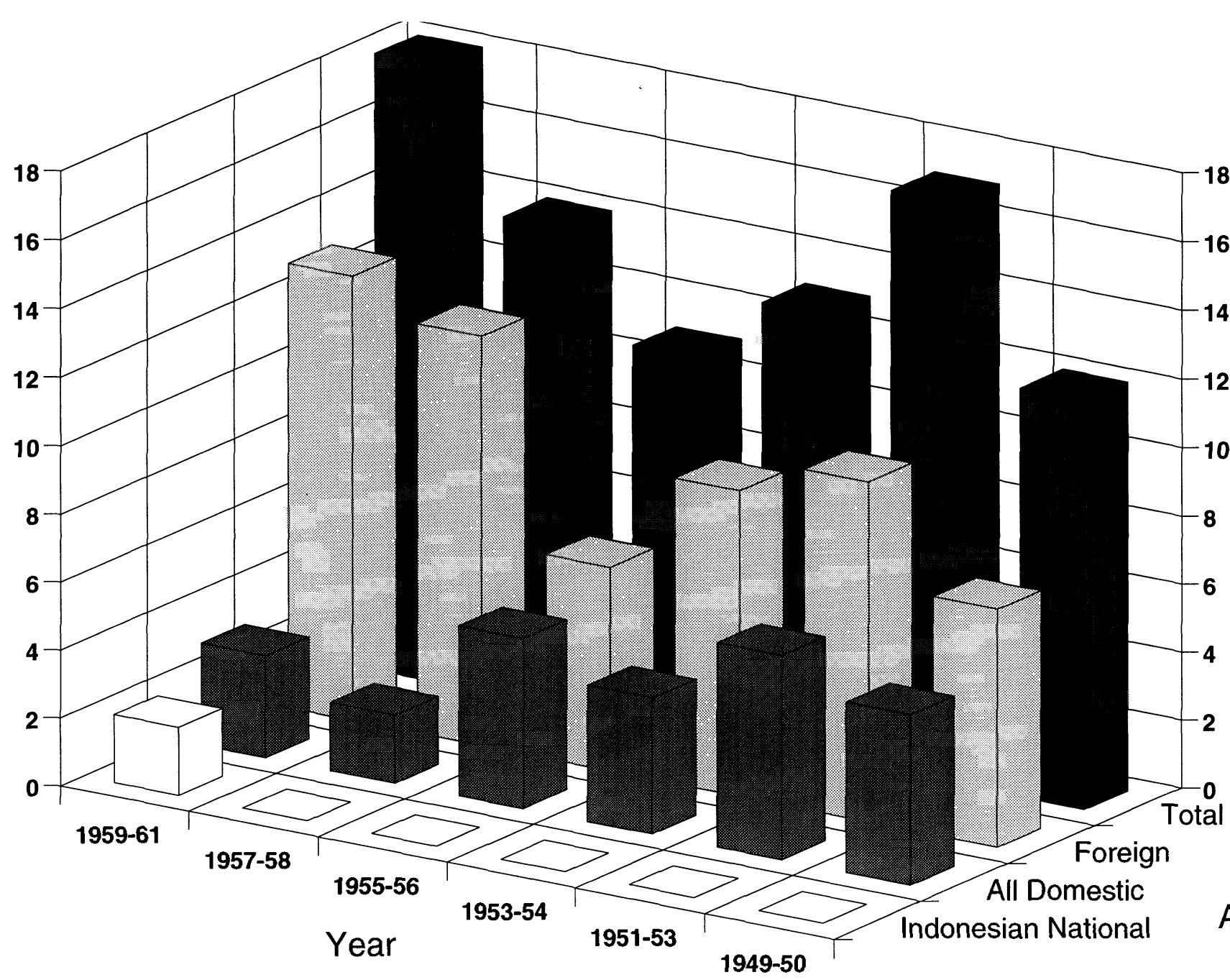

Number of Authors

\section{B. Treubia authorship patterns, 1949-1961}

Figure 2. Authorship patterns in scientific journals. Counts were made of all authors listed in the tables of contents. Counts are for the absolute numbers of authors; if an author published more than one article in a year, the name was counted only once. Domestic or foreign categories refer to the author address given in the paper. The category for domestic authors counts all authors residing in Indonesia, regardless of nationality. The number of Indonesians publishing was determined by a subjective analysis of author names. If an address was not provided, an entry was not made in the columns listing domestic or foreign authors, so that this sum may not equal the total number of authors. A. Reinwardtia. Indonesian nationals published papers during the 1954-56 and 1959-61 intervals. B. Treubia. Indonesian authors published papers only in the 1959-1961 interval. 
history, a branch of science which does not require sophisticated instrumentation or statistical techniques, and would thus be relatively accessible to Indonesians at the time; iii) the journals publish original investigations, not compilations of anecdotes; iv) they have an international audience; and v) runs of both journals are available at Cornell.

The analyses shown in Figures $2 \mathrm{~A}$ and $2 \mathrm{~B}$ indicated that, even though many papers were of domestic origin, virtually none of them was written by an Indonesian author until the late 1950s. Even at that point fewer than one-third of all authors were Indonesians. These data suggest that, while the transfer of sovereignty may have encouraged name changes in journals and moved Indonesians into the research institutes, an increase in the number of contributions made by Indonesian scientists to basic natural science journals did not occur for several years. The figures show that some Indonesians are beginning to publish in the period 1959-1961, which might correspond to the length of time ( \pm 10 years) required for the scientific training needed to conduct research.

An analysis of authorship patterns reveals that a large number of foreign scientists contributed to Treubia and Reinwardtia. The differences between the journals in the number of foreign authors relative to the number of authors based in Indonesia are less important than what these figures say about the audience for the journals. Probably because they offered scientific coverage of a unique part of the world, these journals attracted an international audience which provided the momentum for the journals to continue.

Tallies of the number of pages per year, and per volume, also suggest that the natural history journals were relatively stable. Figure 3 shows that Reinwardtia and Treubia maintain substantial annual page counts. That the journals issued roughly the same number of pages per volume is shown in Figure 4. Page counts for the journals published by the Organization for Scientific Research shown in Figure 5, have an opposite trend. From a maximum output of almost 300 pages in 1951, the OSR journals drop to about one-tenth that level by 1954 .

\section{Journals as a Metaphor for Science after Independence}

Examining the demise of the OSR journal provides a useful overview of events following December 1949.The journal chronicled the history of science immediately after the transfer of sovereignty, and at the same time the publication suffered from some of the sideeffects of the change in government.

Some of the most useful information about the journal is contained in the masthead. The general secretary of the OSR, and the editor of the Journal for Scientific Research, G. Broersma, elected to return to the Netherlands at the termination of his contract in early 1952.51 The post of editor stayed vacant for the remaining life of the journal, so publication remained in the hands of the assistant editor and OSR librarian, Miss C. M. Schaap (later Mrs. C. M. C. Greeter), who departed in late $1953 .^{52}$ Following Mrs. Greeter's departure, the journal masthead lists no staff other than an anonymous scientific advisory board.

Masthead notes suggest that there may have been some occasional disruptions between the editorial offices and the printing plant. And as the masthead relates technical difficulties delaying the publication of occasional issues of the journal, annual reports of the OSR record that paper has been warehoused to overcome anticipated shortages.

\footnotetext{
51 Journal for Scientific Research 1 (1952): 57.

52 Ibid. 3 (1954): 1.
} 


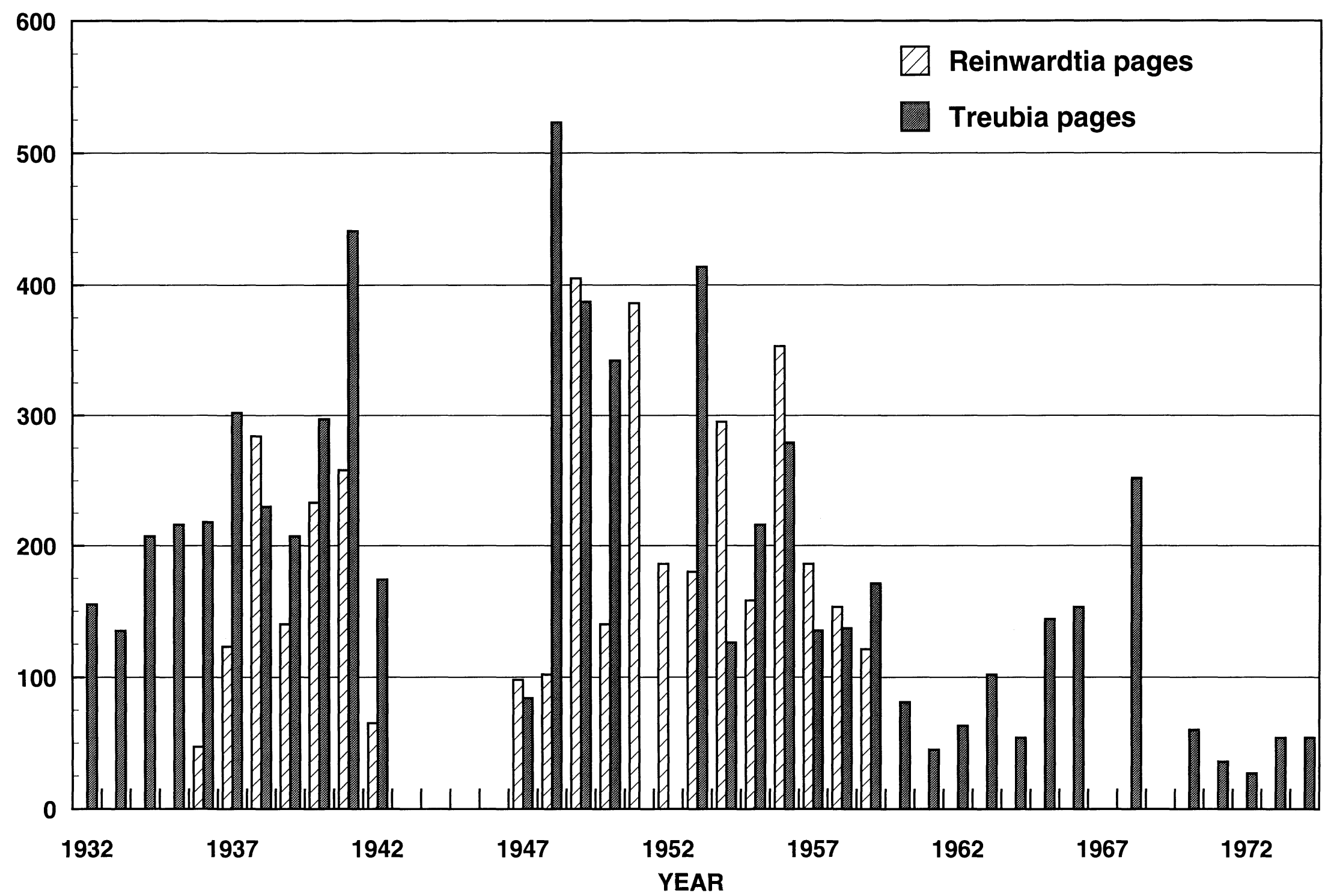

Figure 3. Page counts by year for Reinwardtia and Treubia. The journals were not issued from 1943 to 1946 . Treubia was published in 1951-52, but this volume was not available for inspection. 


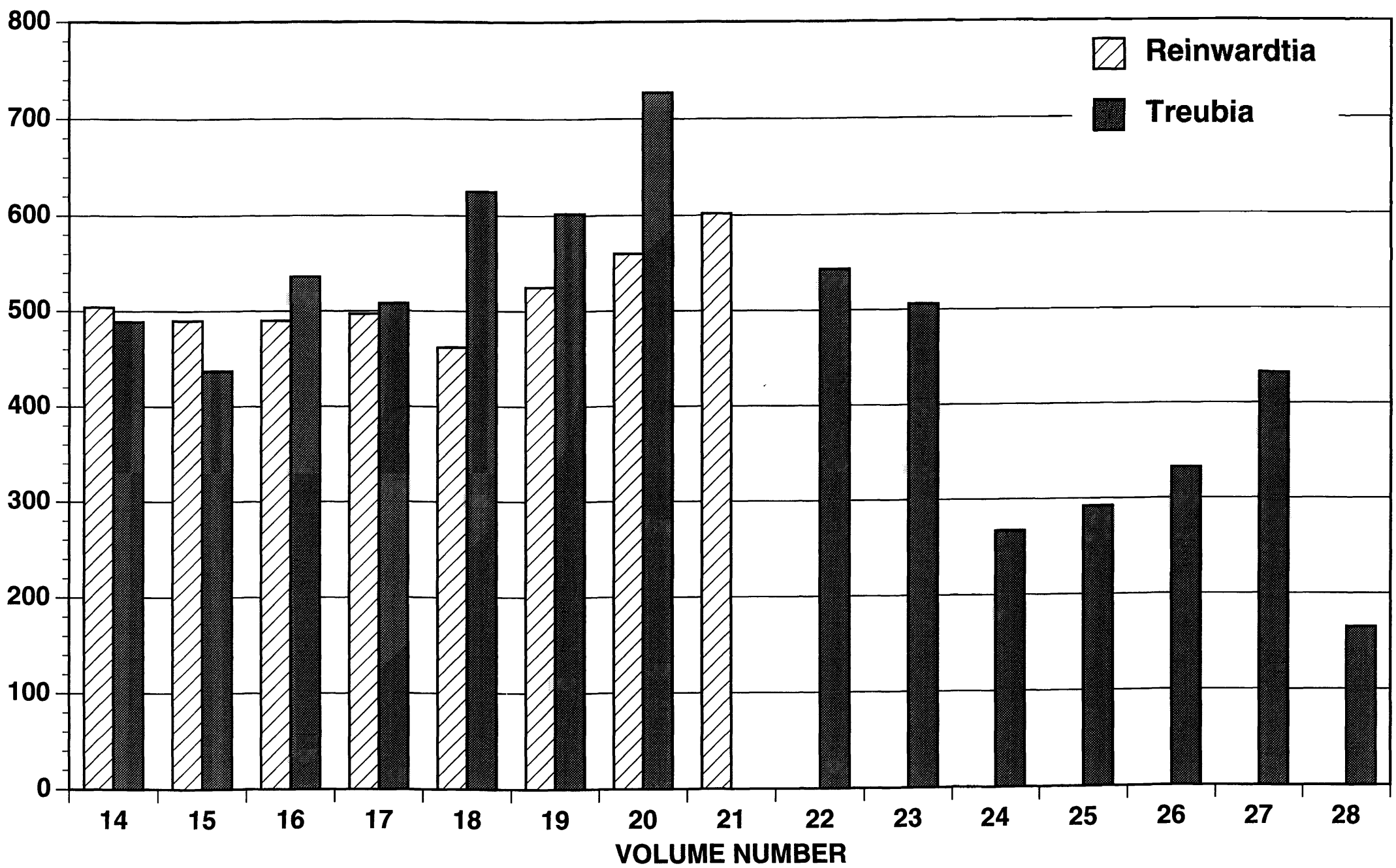

Figure 4. Page counts by volume for Reinwardtia and Treubia. The stability in the number of pages per volume of Reinwardtia is remarkable, and probably indicates that the editors followed a policy of limiting each volume to about 500 pages. Volume numbers are not annual; they often span two or three years. Volume 21 of Treubia was not available for inspection. 


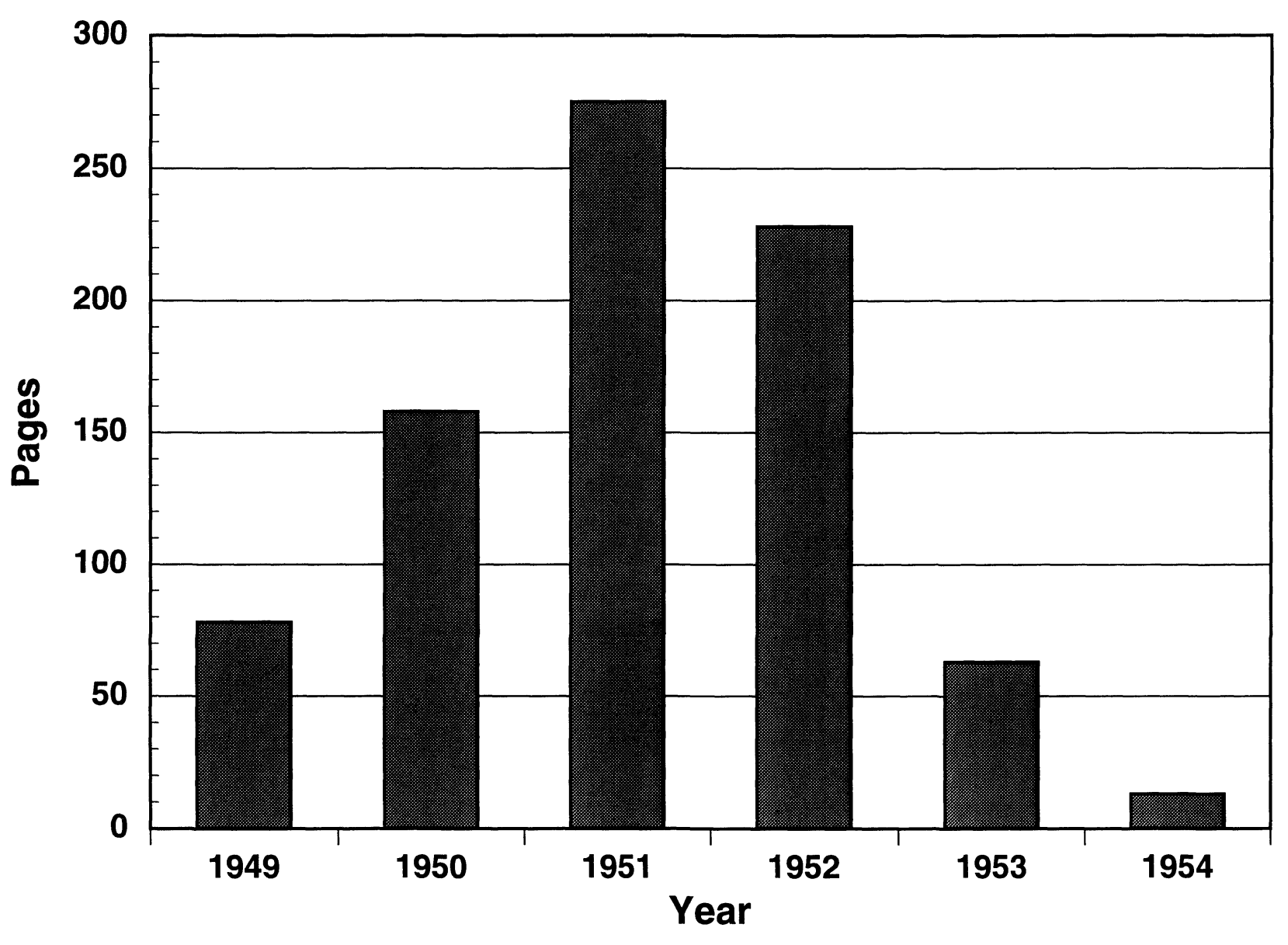

Figure 5. Annual page counts for OSR publications. Tabulations were compiled for all journals listed in Table 2. 
As the Dutch scientists emigrated, the audience for the OSR journals shrank. Although the journals affected an international flair by reprinting UNESCO and other reports, the authors and audience were predominantly expatriate Dutch scientists and engineers residing in Indonesia. When these expatriates returned to the Netherlands, there were few Indonesian scientists available to edit the OSR journal, and no established scientific community to support it.

\section{Consequences of the Transfer of Power on Scientific Research}

Events subsequent to the transfer of power had the unintended effect of eroding much of the scientific research capacity of Indonesia. Economic hardships stymied many research institutions; government budgets were very tight, and could not allow for much research. Nationalist sentiments led to a number of actions which first undermined the existing research structures, and then made it hard to rebuild them. These unforeseen consequences resulted because the culture of scientific research and education had not extended far beyond the Dutch colonizers themselves.

As shown above, prior to World War II, there was an active research establishment in Indonesia, making significant contributions to many fields of basic and applied scientific endeavor. In addition to forming part of the general base of scientific knowledge, these contributions were part of a national scientific culture, published in the prevailing languages (Dutch and English). This research establishment was flawed because it did not include indigenous talent: virtually all of the scientists came from someplace else, and almost no effort was made to educate Indonesian scientists. The departure of the Dutch practitioners of this culture long before they transferred their special knowledge and skills to Indonesians left an infrastructure without the caretakers trained to maintain it.

This problem was compounded as the new government mandated instruction in Indonesian or English, and later went on to outlaw publications in Dutch. These actions, understandable given bitter memories of colonial history and contemporary political crises, had the unintended effect of cutting the country off from the scientific culture which had been established there during the preceding 300 years of the Dutch presence. Whatever became of the libraries in the country after the transfer of power, the literature they contained would have been largely in Dutch. Changing to Indonesian or English language curricula denied students access to the research base established by the Dutch, and meant that the textbooks were not at hand, either because Indonesian editions had not yet been written, or English texts, if available, could not be read by students of the day.

In summary, then, the Indonesian National Revolution interrupted scientific research efforts in following years, because the culture of science established prior to the revolution had not spread to include Indonesian nationals. The unfortunate side-effects were amplified

as Dutch scientists left the country and mandated Indonesian language instruction restricted access to the body of knowledge which had accumulated in Dutch. 